This item was submitted to Loughborough's Research Repository by the author.

Items in Figshare are protected by copyright, with all rights reserved, unless otherwise indicated.

\title{
Coaching journeys: longitudinal experiences from professional football in Great Britain
}

PLEASE CITE THE PUBLISHED VERSION

http://dx.doi.org/10.1080/21640629.2016.1238135

\section{PUBLISHER}

Taylor \& Francis Group (@ 2016 Informa UK Limited)

\section{VERSION}

AM (Accepted Manuscript)

\section{PUBLISHER STATEMENT}

This work is made available according to the conditions of the Creative Commons Attribution-NonCommercialNoDerivatives 4.0 International (CC BY-NC-ND 4.0) licence. Full details of this licence are available at: https://creativecommons.org/licenses/by-nc-nd/4.0/

\section{LICENCE}

CC BY-NC-ND 4.0

\section{REPOSITORY RECORD}

Watts, Darren W., and Christopher J. Cushion. 2019. "Coaching Journeys: Longitudinal Experiences from Professional Football in Great Britain”. figshare. https://hdl.handle.net/2134/22744. 


\title{
Coaching journeys: longitudinal experiences from professional football in Great Britain
}

\author{
Darren W. Watts and Professor Christopher J. Cushion
}

School of Sport, Exercise and Health Sciences, Loughborough University, Loughborough, $\mathrm{UK}$

The aim of this research was to consider the coaching journeys of eight experienced professional football coaches. In-depth semi-structured interviews were conducted over two data points, a decade apart, and analysed thematically. Findings explored the coaches' longitudinal professional playing and coaching experiences, including their learning and development and engagement with formal coach education over four decades. The coaches' narratives highlighted how their biographies had shaped their identities, learning and practice. Each coach emphasised the importance of experiential learning, learning from other coaches, practicing in diverse coaching domains, and the on-going nature of learning. Data highlighted limitations in formal decontextualised coach education and 'fast-tracking'. Findings also illustrated something of the changing nature and demands of coaching and how the coaches have adjusted their practice in order to meet the contemporary demands and expectations of their athletes. The coaches reported they required greater education and support around this area. Coaches' journeys are an under-utilised resource and have implications for future coaching practice, coach learning and coach education development.

Keywords: coach learning; biography; coach education; identity 


\section{Introduction}

Interest in coach learning has grown significantly as an area of study with several theoretical approaches recently proposed as a means to deepen understanding, these include behaviourist and social cognitivist (Groom, Nelson, Potrac \& Coyles, 2016; Thomas, Morgan \& Harris, 2016), experiential (Day \& Newton, 2016), humanist (Coulter, Gilchrist, Mallett \& Carey, 2016; Rowley \& Lester, 2016), constructivist (Toner, Moran \& Gale, 2016; Potrac, Nelson, Groom \& Greenough, 2016), critical (Nelson, Potrac, Groom \& Maskrey, 2016) and social and ethical (Cushion \& Townsend, 2016; Trudel, Culver \& Richard, 2016). Research considering the effectiveness of formal coach education has been critical (e.g. Stodter \& Cushion 2014; Nelson, Cushion \& Potrac, 2013) due to short bursts of formal coach education being 'low impact' compared with years of coaches' learning mediated by experience and other coaches (e.g. Cushion, Armour \& Jones, 2003). Informal learning is crucial to development (Christensen, 2014), and as such authentic coach learning consists of more than formal engagement; it is also in the unplanned intersection of people, culture, tools and context (Cushion, 2011; Hansman, 2001) and therefore needs to be considered longitudinally (Cushion, Nelson, Armour, Lyle, Jones, Sandford \& O’Callaghan, 2010).

Jones, Armour and Potrac (2004) have suggested coaches’ lives, stories and learning experiences are complex and fascinating. Coaching and learning to coach are socially constructed and thus interwoven in the social structures of the specific sports context in which the coach is learning and practicing (Christensen, 2014) - they are complex practices in a social world (Cushion, 2011). Consequently, there is no such thing as one kind of coach learner, one learning goal, one way to learn, nor one setting in which coach learning takes place (Kilgore, 2001). Indeed, different contexts place contrasting demands on the coach and athlete and therefore impact learning. These may be, for example, ideological, institutional, cultural or social in nature, in addition to being rooted in the age and experience of those taking part (Cushion, 2011). Therefore, knowledge, action and learning are the product and manifestation of a personally experienced involvement with the coaching process (Cushion, 2006), and are linked to an individual's history, attributable to how they were learned. The implications of this for coaching lie in understanding how knowledge and experience are constructed, passed on and become translated within the coaching process (Cushion, 2006), thus being aware of the 'person behind the profession' and of the apparent 'personification and idiosyncratisation' of coaching and coach learning (Christensen, 2014). Therefore, research needs to explore the developmental nature of learning to understand how different 
progressive phases are engaged with by coaches over time, and how these then change coaching identities and practice (Cushion, 2011; Mallett, Rynne \& Billett, 2016). Viewed with this temporal quality, learning is well underway before any coaching course or continuing professional development (CPD) session begins and continues after it has finished (Hager \& Hodkinson, 2009), thus confirming the need to consider coach learning as a more long-term endeavour of identity construction.

Identity has been explored in social theory as a way of placing the person in the context of mutual constitution between individuals and groups (Giddens, 1991). Giddens (1991) described the changing nature of self-identity and that a person actively constructs and revises a story of self that provides a basis for self-identity, "the self is reflexively understood by the person in terms of their biography” (Giddens, 1991, p. 53). There is, therefore, a dialectical relationship between the coach, athlete, the social and context of their work. Coaches are active in trying to make sense of their position and, in this respect, are constantly in a process of identity development (Mead, 1934). Hence, a coach's identity will be influenced by contextual factors that need to be foregrounded to understand the nature of learning taking place. Such an approach ensures that we guard against a literal or compressed concept of learning that confines our interest to short-term cause and possible effect of learning episodes (Cushion, 2011). Therefore, as Purdy and Potrac (2014) argue, understanding coaches' career trajectories and lived experiences might not only provide us with potentially rich insights into coaches' working contexts, but the ways in which they may construct their respective coaching identities, including the emotions that are experienced (Christensen, 2013). We know little about the interconnections between coach education and learning, coaching identities and coaches' practice, particularly in professional sport (Purdy \& Potrac, 2014).

The ways in which coaches learn and are willing to learn will depend on their prior positions, experiences and dispositions (Cushion et al., 2003; Christensen, 2014). For example, Christensen (2009) showed that football coaches' practice rested on experiencebased, incorporated 'practical sense' and 'classificatory schemes' (Bourdieu, 1990, 1998). Whilst it is acknowledged that elite playing careers are not pre-requisites for enhanced coaching efficacy, ex-performers who progress into coaching witness, experience and learn about coaching during their athletic careers (Cushion et al., 2003) and assign value to these experiences (Mallett et al., 2016), developing what Bourdieu (1998) called a socially constructed practical sense toward their daily work. Thus, reflecting on being coached presents an opportunity to learn and enables an exploration of what is understood by the 
constructed notions of 'good' coaches and 'good coaching', thus shedding light on coaches' 'practical sense' and 'classificatory schemes'. Being experienced athletes initially, and then experienced coaches thereafter, can provide valuable accounts about coaches' learning journeys and socially constructed dispositions toward coaching practice, coach education and coach development. Indeed, investigating athletic, coaching and coach development experiences unfolding over time offers an intriguing, comprehensive and highly contextual approach to considering the meta-theoretical dilemma of agency versus structure, as well as one of the basic paradoxes of adult learning (Jarvis, 1993), namely that learning is individually experienced by the coach as a biographical matter and yet it is highly influenced and facilitated by a multitude of sociocultural patterns (Christensen, 2014).

The aim of the current research was to understand the changing biographies and selfidentities of experienced football coaches and how these interacted with perceptions and experiences of their practice, learning and coach education. The origins of coach education with the English Football Association (FA) can be traced back to the 1930s (Barber, 2008), and despite early concerns towards coaching, coach education and a lack of research with certified football coaches (e.g. Jones, 1990, 1992), to date, relatively few studies have specifically investigated learning and coach education with British football coaches. This research goes some way to addressing this. A longitudinal approach was adopted considering coach narratives of identity, context and learning in football at two points over a ten-year period. The coaches also considered the 'best' coaches they had played for, or coached with, to aid understanding into the construction of coaching dispositions informed by such notions of the 'good' coach and 'good coaching' and how these may also evolve over time. Therefore, the purpose was to gain insight from a sample of experienced coaches whose 'involvement' with football coaching could exceed that of many coach educators, programme designers and coaching scholars. 


\section{Methodology}

\section{Research Context}

Coaches in England are certified to coach by the FA through UEFA (the Union of European Football Associations) - the governing body of football in Europe. There are five levels: UEFA ‘Pro’ License (Level 5), UEFA ‘A’ License (Level 4), UEFA 'B’ License (Level 3), UEFA 'C' Coaching Certificates (Level 2) and UEFA 'D' Assistant Coach (Level 1). The FA also launched three age-related 'Youth Coaching Modules' (YCM) targeting coaches working with young players representing a 'brand new approach to coaching' (FA, 2009). All coaches attended 'in club' CPD training, and mandatory (FA) CPD provision was introduced following the first data collection period. None of the coaches had entered tertiary education.

\section{Participants}

Participants were purposively selected using criterion-based sampling; this approach was adopted to ensure the participants were ‘information rich’ (Sparkes \& Smith, 2014). This resulted in eight coaches participating in both phase one and ten years later in phase two. Participants were required to have a minimum of both ten years' professional playing and coaching experience in a professional club in Great Britain. These durations meant participants were exposed to sustained involvement with elite-level coaches, providing a good opportunity to learn about coaching as athletes (Cushion et al., 2003), and also experienced coaches that had practiced in different contexts. To protect anonymity, pseudonyms were used (Table 1, p. 7). 
Table 1. Representation of coaches' experience, qualifications and present role.

\begin{tabular}{|c|c|c|c|c|c|}
\hline Coach & $\begin{array}{l}\text { Coaching } \\
\text { experience } \\
\text { (years/ } \\
\text { roles) }\end{array}$ & $\begin{array}{l}\text { Playing } \\
\text { experience } \\
\text { (years/level) }\end{array}$ & Qualifications & $\begin{array}{l}\text { Coach } \\
\text { education } \\
\text { experiences }\end{array}$ & $\begin{array}{l}\text { Current } \\
\text { coaching } \\
\text { role }\end{array}$ \\
\hline Tom & \begin{tabular}{l}
\multicolumn{1}{c}{20 years } \\
First Team \\
U18 Youth team \\
Academy \\
Participation
\end{tabular} & $\begin{array}{l}18 \text { years } \\
\text { Premier \& } \\
\text { Championship }\end{array}$ & $\begin{array}{l}\text { UEFA A; YCM 1-3 } \\
\text { Academy Manager's } \\
\text { License }\end{array}$ & $\begin{array}{l}\text { 1980s- } \\
\text { 2010s }\end{array}$ & $\begin{array}{l}\text { Academy } \\
\text { Manager }\end{array}$ \\
\hline Luke & $\begin{array}{l}17 \text { years } \\
\text { First Team } \\
\text { Reserve team } \\
\text { U18 Youth team } \\
\text { Academy } \\
\text { Participation }\end{array}$ & $\begin{array}{l}16 \text { years } \\
\text { Premier } \\
\text { European } \\
\text { International }\end{array}$ & $\begin{array}{l}\text { UEFA A } \\
\text { YCM } 1\end{array}$ & $\begin{array}{l}\text { 1990s- } \\
\text { 2010s }\end{array}$ & $\begin{array}{l}\text { First } \\
\text { Team } \\
\text { Head } \\
\text { Coach }\end{array}$ \\
\hline Richard & $\begin{array}{l}23 \text { years } \\
\text { Reserve team } \\
\text { Youth team } \\
\text { Academy } \\
\text { Participation }\end{array}$ & $\begin{array}{l}13 \text { years } \\
\text { Premier } \\
\text { European } \\
\text { International }\end{array}$ & $\begin{array}{l}\text { UEFA B } \\
\text { YCM } 1\end{array}$ & $\begin{array}{l}\text { 1990s- } \\
\text { 2010s }\end{array}$ & Academy \\
\hline Fred & $\begin{array}{l}13 \text { years } \\
\text { First Team } \\
\text { Youth Team } \\
\text { Academy } \\
\text { Participation }\end{array}$ & $\begin{array}{l}14 \text { years } \\
\text { Premier \& } \\
\text { Championship }\end{array}$ & $\begin{array}{l}\text { UEFA A; YCM 1-2 } \\
\text { Coach Educator } \\
\text { (Levels 1-2) }\end{array}$ & $\begin{array}{l}\text { 1990s- } \\
2010 s\end{array}$ & $\begin{array}{l}\text { Academy } \\
\text { \& Coach } \\
\text { Educator }\end{array}$ \\
\hline James & $\begin{array}{l}21 \text { years } \\
\text { Academy } \\
\text { Participation }\end{array}$ & $\begin{array}{l}\quad 14 \text { years } \\
\text { Premier } \\
\text { European } \\
\text { International }\end{array}$ & $\begin{array}{l}\text { UEFA B } \\
\text { YCM 1-2 }\end{array}$ & $\begin{array}{l}\text { 1990s- } \\
2010 s\end{array}$ & Academy \\
\hline Mike & $\begin{array}{l}24 \text { years } \\
\text { Academy } \\
\text { Participation }\end{array}$ & $\begin{array}{l}14 \text { years } \\
\text { Premier }\end{array}$ & $\begin{array}{l}\text { UEFA B } \\
\text { YCM } 1\end{array}$ & $\begin{array}{l}\text { 1980s- } \\
2010 s\end{array}$ & Academy \\
\hline Peter & $\begin{array}{l}20 \text { years } \\
\text { First Team } \\
\text { Youth team } \\
\text { Academy } \\
\text { Participation }\end{array}$ & \begin{tabular}{l}
\multicolumn{1}{c}{13 years } \\
Premier \\
European \\
International
\end{tabular} & $\begin{array}{l}\text { UEFA A } \\
\text { YCM } 1\end{array}$ & $\begin{array}{l}\text { 1990s- } \\
\text { 2010s }\end{array}$ & Academy \\
\hline John & $\begin{array}{l}20 \text { years } \\
\text { Academy } \\
\text { Participation }\end{array}$ & $\begin{array}{l}16 \text { years } \\
\text { Premier \& } \\
\text { Championship }\end{array}$ & $\begin{array}{l}\text { UEFA B } \\
\text { YCM } 1\end{array}$ & $\begin{array}{l}\text { 1990s- } \\
\text { 2010s }\end{array}$ & Academy \\
\hline
\end{tabular}


The participants were similar in age ( $M=51$ years) and were experienced coaches ( $M$ $=20$ years), resulting in a combined total of 160 years coaching experience. Formal coach education experiences varied between three and four decades, and each coach had similar journeys commencing in participation and then developmental contexts; four then progressed to performance (head coach) contexts (Premier League and/or Championship League) (Lyle, 2002). However, at phase two six coaches were academy coaches, one was a first team head coach and one was an academy director. Professional playing experience ( $M=15$ years) included Premier and Championship levels for all participants; four experienced international representation (under different head coaches) and European club competition. Combined playing and coaching experiences provided a total of 280 years $(M=35$ years).

\section{Procedure}

Following institutional ethics approval in-depth, semi-structured interviews were used to investigate the participants' lived experiences, perceptions and how they assigned meanings within their contexts and cultures (Atkinson, 2012). Related studies have also adopted a similar approach (e.g. Chesterfield, Potrac \& Jones, 2010; Christensen, 2014) and Purdy (2014) advocates this in sports coaching research, highlighting its potential for gaining 'rich' insights.

\section{Phase One}

An interview guide that incorporated open-ended questions was used as a framework to facilitate the interviews. 'Freedom' when responding was an essential part of the interview process (Jones et al., 2004; Nelson et al., 2013). Both authors and a further researcher familiar with qualitative research methodology and had also both performed and coached within the study's contexts reviewed the interview guide and participated in pilot interviews. Collective feedback was considered and minor modifications were made to two questions to enhance clarity.

The interviews were conducted at respective training grounds and included questions based on the participants' development and their experiences of coach education. The interview guide consisted of the following areas: (a) demographic and background information (e. g. coaching history, formal qualifications, current coaching role, contexts practiced in); (b) personal coaching development and learning (e. g. playing and coaching experiences, key areas identified to aid practice; (c) perceptions of formal coach education experiences (e.g. courses and content, assessment, CPD and coach educators); perceptions of 
their 'best' coach and 'good' coaching; (d) 'the future' - 'of coaching', 'performers', coach development and learning, and coach education. The interviewer investigated certain areas further through 'elaboration' techniques (Potrac, Jones \& Armour, 2002; Sparkes \& Smith, 2014). Interviews were tape-recorded and transcribed verbatim.

\section{Phase Two}

Phase two occurred ten years later and the same procedure was followed. Interviews were conducted at respective stadiums or training grounds $(n=5)$, telephone interviews $(n=$ 2) and homes $(n=1)$. Due to two of the coaches' schedules telephone interviews were used. Questions were aligned closely with phase one; however, prior to phase two's interviews commencing, a thirty-minute informal discussion was conducted to review phase one's interviews. Coaches were also asked about the changes to coach education and their practice. For example, did they 'coach differently', had perceptions of their 'best' coach and 'good' coaching changed, and their thoughts around 'the future' - 'of coaching', 'performers', coach development and learning, and coach education, were sought.

On average, interviews lasted ninety minutes. Across both phases, each coach was interviewed for three hours. Twenty-four hours of interview data were collected along with four hours of informal conversation resulting in three hundred and sixty pages of transcription.

\section{Data analysis}

Thematic analysis was used as it offered accessibility, theoretical flexibility and is not reliant on a pre-existing theoretical framework (Braun \& Clarke, 2006; Patton, 1990). The approach undertaken enabled the data to be considered at both a semantic and latent level. Therefore, the data analysis process was an inductive thematic analysis conducted in a 'contextualist' manner; epistemologically, this approach lies between essentialism and constructionism in attempting to reflect and unravel 'reality' through individuals' meaning making whilst recognising social influences. Phase one's data were thematically analysed retrospectively and in conjunction with data from phase two using a data-driven, recursive and semantic approach (Braun \& Clarke, 2006). This process commenced with immersion in the data that led to the transcripts being read three times; data-driven manual open coding was conducted using a constant comparison method (Strauss \& Corbin, 1990). From here, predominant patterns of meaning (explicit themes) were sought across the entire data set. Thematic categories were identified, cross-checked, reviewed and, if necessary, further 
defined and named; finally, vivid data extracts were used to report findings (Sparkes \& Smith, 2014). In addition, an interpretative - therefore more theoretical - latent analysis was also undertaken on parts of the data deemed to be worthy of a higher level of consideration (Frith \& Gleeson, 2004; Braun \& Clarke, 2006; Patton, 1990). The analyses provided rich, detailed and complex accounts and theoretical consideration of experiences, meanings, the coaches' realities and culture (Braun and Clarke, 2006; Atkinson, 2012). Prevalent semantic themes were (a) early days - player to coach; (b) learning about 'good' coaching and coaches; (c) moving on 'becoming' a coach; (d) moving up - 'becoming' a development and performance coach; (e) moving on - 'becoming' a contemporary coach. It was hoped that the authors' efforts to interpret the data were appropriate; however, we acknowledge the subjective nature of coding, theme creation and pre-existing theoretical and epistemological commitments (Braun \& Clarke, 2006).

\section{Results and Analysis}

\section{Early Days — player to coach}

There is a strong relationship between learning and identity. Lave and Wenger (1991) describe learning as involving the construction of identities, that is the historical production, transformation and change of persons (Cushion, 2011). However, identity in psychologically informed coaching research has tended to treat identity simply as self-concept, that is knowledge of self or 'intrapersonal knowledge' (e.g. Côté \& Gilbert, 2009) that is as epistemological (Cushion \& Townsend, 2016; Lave \& Packer, 2008; Packer \& Goicoechea, 2000). Instead, "identity is linked to participation and learning, as a socially situated activity that must be grounded in an ontology that conceives of the person as an active being, engaged in activity, in the world” (Cushion \& Townsend, 2016, p. 191; Lave, 2009). Seen as such, the learner is always 'becoming' (i.e., their identity is being developed, transformed) and always situated in a context that is 'becoming' (i.e., changing situations) (Colley, Hodkinson, \& Malcom, 2003). Within such a conceptualisation the focus is on learning as social participation, or a "process of being active in the practices of social communities and constructing identities in relation to these communities (Wenger, 1998, p. 4). In this study, all the coaches had been high achievers as players and had been active in constructing a connection to the game through a playing identity and this was integral to forming their coaching identities. 
Playing football was all I knew. I had a good playing career and took this into my coaching. My early coaching years were set up by what I had experienced as a player, and I coached how I was coached - it was all I knew. (Fred)

I remember starting off and doing my coaching badges. The whole thing felt artificial and as I'd been in the game so long I knew you couldn't work like this. It was just so unrealistic and regimented. Fortunately, I had my own playing experience to draw upon and it did help me a bit back then. (Richard)

It was a massive advantage being a player - not only because you had a chance to learn the game and see what was needed at the top level - but I was exposed to different coaches. I'm actually not sure this helped me that much in my early years, as it was totally different. Though I always knew how important communication was, as I valued this from my playing years when I saw it first-hand. (Mike)

Such experiences provided the participants with an opportunity to learn about coaching through an 'informal apprenticeship’ (Cushion et al., 2003), creating both a platform for their practice as they transitioned into coaching, but also a lens through which judgements about coaching and coach education were made. As a result, feelings towards coach education and coach educators were quite negative; coaches also felt educators lacked the necessary coaching experiences and identities.

Being in the game for a long time gave you real experience. The courses were a long way off this reality. That's why it was difficult accepting and even respecting the courses and the guys running them...they were telling us what to do, but they did not know what it was really like. (Mike)

I just didn’t agree with many points the tutors made and how they did things. (James)

\section{Learning about 'good' coaching and coaches}

Playing experiences laid foundations that can be traced through all of the participants' experiences and beliefs about 'good' coaching. For example, 'communication' and 'relationships' were important threads reported throughout about their own practice and their learning as Mike explains:

He had the knack of getting the best out of all the players. You knew he treated people differently, and it worked because people are different. You never thought he favoured certain players over others. He would tell us what he thought of us, it was measured and felt special and it was personal and genuine. He could make you feel unbeatable and if you were not yourself or had a problem he would almost instantly notice this. He had this rapport with everyone...these things have been important for my coaching. I try to make my players feel the same way, the way he communicated with us and the impact it had on us was so powerful. 
He cared about us. He was a decent man with principles. He got massive respect from the lads. We almost won the league (Premier) and FA Cup. Many of us were rejects...but he just had this aura about him - you wanted to do it for him. He focused on our strengths as players and as a team, but was very good at protecting our weaknesses. His organisation and attention to detail was second to none. He would also ask us about our thoughts. Back 'in the day', not many did that... he would still 'cut it' now. (Tom)

In addition, 'knowledge of the game', 'open-mindedness', 'flexibility' and making coaching sessions 'fun/enjoyable' were key attributes of their 'best' coaches. Although, there was recognition that learning and 'good' coaching may not be exclusively 'fun' or 'enjoyable'.

(Assistant Coach) made it different, made it enjoyable, still working hard, but exciting. So you looked forward to training and you need to come in as a professional footballer looking forward to it. (Luke)

He (Head Coach) knew exactly what he wanted from his players. He wasn't the greatest day-to-day, in fact you didn't really want to see him that often, but when it came to organising team shape, and even at times when you thought this is a bit ritual and boring, actually as you get older you realise it was the right thing to do. I suppose I have taken the best bits from both (coaches). (Luke)

Even at the pro level, and the pressure that went with it, the better coaches made training enjoyable and fun. (Richard)

These experiences as players, and reflection upon them, continued to guide and inform the coaches' practice throughout and could still be identified as themes reported in perceptions about their current practice where the coaches identified and valued, what is described in contemporary terms, as 'athlete-centered' (Kidman \& Lombardo, 2010) or 'humanistic' (Lyle, 2002) approaches, with the view to 'getting the best out of all your players'. (Peter)

\section{Moving on - 'becoming' a coach}

The data provides some support to the notion that activities central to identity generation are grounded in practice and learners participation (Cushion \& Townsend, 2016); promoting the conceptualisation of learning in coaching as a process of 'becoming', changes in identity must arise from growth of the person and knowledge (Cushion, 2011; Packer \& Goicoechea, 2000). Therefore, individual coaches' learning cannot be defined as separate from their change in social identity (Bredo, 1994) thus challenging "cognition alone as an adequate way of thinking about learning - learning involves the construction of identities” (Cushion \& Townsend, 2016, p. 191; Lave \& Wenger, 1991). The processes, relationships and 
experiences that constituted the participants' sense of identity and belonging underpinned the nature of their subsequent learning as they moved through the social space. So from being players the participants 'became' coaches - and these initial experiences were with coaching children. Hence, their newly forming coaching identities were subjected to challenges from coaching children of mixed ability and different age groups. These initial coaching experiences challenged the coaches' 'ontological security' (Giddens, 1987) and were emotional experiences laden with feelings of isolation, frustration, regret and vulnerability:

I remember trying to coach the wrong things and trying to complicate sessions. I got frustrated with the kids but it was me who was in the wrong. To this day, it's not something that I feel very proud about, and this isn't meant as an excuse, but when I look back I didn’t know any different. (Richard)

I just remember thinking they're (the children) nuts! I tried to deal with them how I was dealt with, and quickly realised I was out of my depth! I even remember giving one lad laps as a punishment for not listening and it was baking hot. I was totally exposed. (Luke)

Some of my early sessions were disasters, it really tested me, I had to change and adapt my approach. I didn't have anyone to help me through it... I was in the 'deep end'. (James)

These experiences created what has been described as a 'disjuncture' (Jarvis, 2006) and challenged perceptions of their own practice against idealised notions of being a 'good coach' and 'good' coaching producing a 'wake-up call', with the realisation that their playing identity alone was not sufficient to deal with these new situations. However, reflecting on these experiences the coaches' clearly valued their early participation coaching; the consensus being it was a 'great learning curve'.

My experiences working with children were really useful. I learnt so much about communicating and dealing with different personalities. I feel I am a better coach for having done this...it was like an apprenticeship, real experience. (James)

Starting out with the kids made me a better coach. I think it would be a good thing for all coaches to do...never mind where you played. You learn so much about them and yourself...even if you don't think you're suited to it, I think it is a good thing. (John)

However, whilst practicing within these contexts they relied on 'trial and error' attempting to learn from their own 'mistakes' to enhance their future practice and develop a coaching identity, as Mike suggests.

They (children) were guinea pigs really I had no idea how to deal with them. I'm sure I could've put some of them off for life. Although I'd like to think I improved, it actually took me a quite a long time to realise that I was not 'up-to-it'. For a while I probably 
blamed them - I suppose I was quite defensive. I was not used to failure or not being in control. (Mike)

The coaches appreciated these experiences as they allowed a recognition of the complexity of coaching - triggering greater self-awareness - and therefore an acceptance of their own limitations became apparent. They felt they needed help, but did not really know how to get it.

I would almost spy on other coaches with their kids and see what they were doing. I felt this was the only way of improving. (Richard)

Some were 'too proud' to seek it,

I was stereo-typical and stubborn. I had a lot of success as a player, was a club captain, and to be fair nothing phased me. To ask other coaches and confide would have been the best thing to do, but I couldn't bring myself to do it. (Richard)

Whilst some believed at the time that their coaching was fine:

I genuinely believed I was right, they (children) were wrong, and that I was 'wasting my time'. I even used to tell them that! (John)

Importantly, the coaches suggested that their formal coach education did not adequately prepare them for the reality of day-to-day coaching (c.f. Jones \& Turner, 2006).

It's actually ironic that all of the stuff I've said as being important and things my best coaches did, still appears to be a long way off from what the courses offer. (Tom)

Having my 'prelim' (FA coaching certificate) made no difference at all. (James)

Indeed, the coaches felt 'let down' and 'disappointed' by formal programmes that they perceived "have hardly changed in thirty years” (Richard).

You know, their (FA's) approach to coaching hasn't changed and over the years it hasn’t really helped me. (Mike)

Three of the ' $B$ ' Licensed coaches were registered to commence the ' $A$ ' License but were apprehensive whether the ' $A$ ' License would actually enhance their practice. This trend was also reported from the 'A' Licensed coaches' towards the 'Pro' License. Indeed, the coaches add another level of understanding where the reality of knowledge provided by formal coach education is not readily applicable in other contexts. That is, formal learning does not consider the constructive relations between the coaches' practice and their ongoing activity in the world in which they are socially located and engaged (Lave \& Packer, 2008). Therefore, 
formal coach education is low impact, in part, because it has "an idealised picture of unproblematic transmission of knowledge in a uniform world of shared values and uniform culture” (Cushion \& Townsend, p. 193, 2016; Lave \& Packer, 2008), that is in stark contrast to coaches' "reality of socially located people, more or less engaged in ongoing practice, different from one another, in conflict and in unequal relations of power" (Cushion \& Townsend, 2016, p. 193; Lave \& Packer, 2008).

\section{Moving up - 'becoming' a development and performance coach}

An important moment in the development of the coaches' coaching identity was the transition into elite youth developmental coaching contexts, at centres of excellence or academies.

I learned a lot about myself, coaching and coaching children during my early years. I think it made me a better coach for when I progressed to the centre. You know in all ways really: communication, organisation and so on. My knowledge of the game actually wasn't that important at the start but in the centre it was. So it provided a useful combination and married up with my knowledge of the game. (James)

It made me consider things that I would have never considered before. Am I communicating correctly, organisation, do they really understand, is this the best way? If you struggle with these, I think they get highlighted sooner with mixed ability kids, and you can actually lose them and a session quickly. If I'd gone straight into the academy coaching set-up, I would not have realised this so quickly. (Tom)

The coaches spent a period of coaching based at one club, and five of the coaches had also played professionally for the club where they were now employed to coach - having a valued and respected identity and significant social and cultural capital within that organisation (Cushion \& Jones, 2006). As a result, the coaches reflected upon the learning that came from the valuable relationships with the other coaching staff, ranging from first team to age group coaches. As part of this process, the coaches explained that formal and informal meetings, including phone calls and peer observations were commonplace and perceived these to be excellent learning opportunities.

I think that the way (to learn) is to listen to people in the game, other coaches, we've got (coach's name) who fortunately I work with and I feel he is a very good coach and if I need to do things I always ask him. I ask (coach's name) or other coaches in the club how can I get the best out of this, what could I do for that. We learn a lot off of each other. People have asked me the same things so I think you learn more off of one another. Comrades in the club basically, I go that way. (Luke)

You know, chatting to other coaches within the club, watching their sessions, and viceversa was superb, and still is, you just keep learning. The coaches within the club are very different in many ways, and work with different players of different ages. (James) 
It is like a family. We don't always agree though (laughs). We'll take note of anything that will help us, but obviously we will protect and share stuff that we think works for us. You know, we're in competition with other clubs. (John)

These examples suggest something of coaches learning and development as a community of practice (Lave \& Wenger, 1991) providing "the interpretive support necessary for making sense of its heritage” (Lave \& Wenger, 1991, p. 98) rather than simply a repository for technical knowledge and skills (Cushion \& Townsend, 2016). Therefore, the coaches' participation in the cultural practices of the club as well as its associated knowledge and application were all connected; their location within the community therefore impacted on meanings negotiated related to social practice. In drawing on theories of social practice (e.g. Bourdieu, 1977; Giddens, 1979), Lave and Wenger (1996) emphasise the relational interdependency of not just the individual and social world but activity, meaning, cognition, learning and knowing (Cushion, 2011; Cushion \& Townsend, 2016). By situating learning within social and cultural contexts the coaches' direct experience of social practice meant that they were less involved with objective decontextualised knowledge acquisition, but were constantly constructing knowledge (Cushion \& Townsend, 2016). Hence, "participation in social practice - subjective and objective - suggests an explicit focus on the person but as person-in-world, as a member of the socio-cultural community" (Cushion \& Townsend, 2016, p. 192). Importantly, this learning was valued because it was part of the coaches' everyday practice, and not set apart and understood as a separate process existing of its own sake. Indeed, the coaches all highlighted 'in-house' CPD within their professional clubs as being far more 'useful' and 'realistic' (than 'external' FA CPD).

We had a (CPD) session put on for us about eight months ago by (first team coach) at (Championship club)...he came along and it was a really good session..I can use that. (Luke)

The FA (CPD) stuff that we must attend is just very basic. It's just a tick box (exercise) really. So far, there's nothing that has really helped us. (John)

This perhaps highlights the problem of understanding and presenting learning as separate, where learning is something that must take place elsewhere rather than in the circumstances in which what is learned is supposed to be 'applied' (Cushion \& Townsend, 2016; Lave \& Packer, 2008). These can create divisions between learning and using knowledge, and linear relations in time between learning 'before' to use 'after' (Lave \& Packer, 2008). This in turn 
creates a division between learning and practice where the 'coach education' is 'not relevant' to the coach's day-to-day practice.

I just don't think courses help us enough... and a lot of the stuff we're being told what to do and how to do things, in my experience, doesn't actually work for me - a lot of it's unrealistic. (Mike)

\section{Moving on - 'becoming' a contemporary coach}

Coaching practice has an historical character that is seldom discussed in relation to coach learning - with coaching considered a 'constant'. However, for the coaches, meaning was negotiated within practices in an on-going interaction of the historical and the contextual; that is, "social practice, cognition and communication in, and with, the social world are situated in the historical development of on-going activity" (Cushion \& Townsend, 2016, p. 193; Lave \& Wenger, 1996). This means that the coaches' learning process can be considered as the "historicising of the production of persons" (Lave \& Wenger, 1996, p. 146). Therefore, the coaches are "historically produced in practice in relation to the identities, cultural genres and artefacts that are central to the cultural activities in which they engage; sense-of-self forms in relation to cultural activities where identities are in flux and unsettled” (Cushion \& Townsend, 2016, p. 194; Holland \& Lave, 2009). In this respect, the coaches were able to reflect not only on changes in themselves over the period but also perceived changes in performers; for example, questioning and challenging coaches was not something, until the last ten years, the participants had much experience of as players, or, until recently, as coaches.

I have changed a lot from ten years ago - it is a lot harder now - it's hard to know how to communicate with some of them to get the best out of them...I need to improve and to change to have a better impact on some of them. I've had to become a lot more patient... (Fred)

Coaching has changed and I have had to change. You know, I now have to think more...what makes him tick, you know. It's frustrating and harder nowadays. But challenge can be a good thing you know, it makes me question what I do more. It's similar to when I started out with the kids. Loads of deep thinking, reflecting. At least now I have others (coaches) around me to discuss these issues with. (Luke)

Players challenge you more now and ask more questions and are more opinionated; and probably have more power over coaches than years ago. But when you scratch beneath the surface of some of them they are probably more sensitive and vulnerable nowadays - not as strong mentally. We need extra help with some of the issues. It's harder these days - in some ways I feel I was better ten years ago. (Tom) 
There are times when I feel they have too much to say. When I played it was the opposite - we rarely challenged the manager (coach) or staff. Now I am not saying that was right or how it should be now, but that's how it was. I feel that there comes a point when I do know better, otherwise why am I here?! I think it is a broader society thing in this country - I actually think it is a problem for our game. Don't get me wrong some of the questioning and challenging is good for me as a coach - it does make me reflect more and run it by others (coaches), but I think there is too much of it. (Tom)

These perceived changes and the demand to meet these changes again put further pressures onto, and concerns regarding the efficacy of, coach education - raising historical issues that had not been addressed:

I said last time (ten years ago) about a total lack of assistance for dealing with and coaching players of different levels and age-groups. As I worked at centre of excellence and grass roots (levels) then it was obvious that a lot of the (formal) stuff delivered and how it was done couldn't be used - it was rigid and one way to coach. In my opinion apart from a little bit of sports science and first aid, (formal) courses have hardly changed in thirty years. (Richard)

However, the coaches did feel that the more recent but 'overdue' introduction of the YCMs offered 'something different' providing a moment of change to coach education. Indeed, as players and coaches the participants felt the 'best' coaches they performed under and seen were excellent communicators, but acknowledged this area had become more challenging in their own practice in recent years. Related research (e.g. Chesterfield et al., 2010) has indicated this area has not been well-served in coach education, but positive findings (e.g. Quinn, Huckleberry \& Snow, 2012) do exist.

\section{Concluding thoughts}

Talking to coaches across time in separate decades has enabled more than a 'one-off' exploration of biography, identity, learning, and perceptions of coaching and coach education. The findings are significant in showing the developmental nature of the coaches' learning and how different coaching career 'phases' were engaged with over time and their impact on the coaches' identities and practice. The current study provides some of the first evidence explaining how learning has a temporal quality through interaction in practice in social contexts where coaching and learning to coach is complex. The findings provide evidence of learning as continuous and as a part of ongoing social practice. This highlights the error for coach education in thinking of learning in coaching as a special kind of activity taking place only at particular times in special places arranged for it (Lave \& Packer, 2008). An appreciation of this and by examining the coaches' progression through different levels of the sport the study has provided an increased understanding of 
the reasons why 'decontexualised' formal coach education courses, fast-tracking and CPD are low impact.

The coaches in this case provide support for the idea of a coaching 'apprenticeship', 'starting at the bottom' and 'learning their trade'. Working in different domains, from mixed ability children in a participation context - then moving to developmental and then first team roles - provided vital developmental opportunities for reflection, observing and liaising with other coaches and contributed to shifting coaching identities and the notion of 'becoming' a coach. These experiences facilitated the realisation of the challenges of 'coaching', and, in turn, produced a 'disjuncture' (Jarvis, 2006). Whilst durations varied, each coach appeared to use this disjuncture to inform future learning and practice. At the same time, these experiences provided both a filter and a standard against which 'good coaching' and formal coach education were judged and resulted in the coaches remaining sceptical towards attending future formal provision.

The coaches' experiences left them with clear views on the shaping of their own learning needs and coach education - these included: more focus on flexible approaches around how to coach; greater emphasis on communicating with their athletes; developing more pedagogical awareness - including an understanding of learning; a need for pedagogically focussed CPD; and a compulsory period of observing different coaches (and raising awareness of domains) at the beginning of coaches' journeys and engagement with coach education. Such perspectives are important when these coaches' 'involvement' with coaching could exceed that of many coach educators, programme designers and coaching scholars, and such an approach seems a fruitful avenue for future research that could offer a nuanced and detailed data-driven insight to coaching practice, coach learning and coach education development.

\section{References}

Atkinson, M. (2012). Key concepts in sport \& exercise research methods. London: Sage. 
Barber, D. (2008). Football Association Historian (telephone communication, $4^{\text {th }}$ Feb). In P. E. Robinson (Ed.). (2010). Foundations of sports coaching. (pp. 7-8). London: Routledge.

Bourdieu, P. (1977). Outline of a theory of practice. Cambridge: Cambridge University Press.

Bourdieu, P. (1990). The logic of practice. Cambridge: Polity Press.

Bourdieu, P. (1998). Practical reason: On the theory of action. Cambridge: Polity Press.

Braun, V. \& Clarke, V. (2006). Using thematic analysis in psychology. Qualitative Research in Psychology, 3, 77-101.

Bredo, E. (1994). Reconstructing educational psychology: Situated cognition and Deweyian pragmatism. Educational Psychologist, 29, 23-35.

Chesterfield, G., Potrac, P., \& Jones, R. (2010). 'Studentship' and 'impression management' in an advanced soccer coach education award. Sport, Education and Society, 15, 299-314.

Christensen, M. K. (2014). Exploring biographical learning in elite soccer coaching. Sport, Education and Society, 19, 204-222.

Christensen, M. K. (2013). Outlining a typology of sports coaching careers: Paradigmatic trajectories and ideal career types among high-performance sports coaches. Sports Coaching Review, 2, 98-113.

Christensen, M. K. (2009). “An eye for talent”: Talent identification and the "practical sense” of top-level soccer coaches. Sociology of Sport Journal, 26, 365-382.

Colley, H., Hodkinson, P., \& Malcom, J. (2003). Informality and formality in learning: A report for the learning and skills research centre. London: Learning and Skills Research Centre.

Coulter, T., Gilchrist, M., Mallett, C., \& Carey, A. (2016). Abraham Maslow: Hierarchy of coach and athlete needs. In L. Nelson., R. Groom., \& P. Potrac (Eds.), Learning in sports coaching: Theory and application (pp. 63-74). London: Routledge.

Côté, J., J. \& Gilbert, W. (2009). An integrative definition of coaching effectiveness and expertise. International Journal of Sports Science and Coaching, 4, 307-323.

Cushion, C. J., Armour, K. M., \& Jones, R. L. (2003). Coach education and continuing professional development: Experience and learning to coach. Quest, 55, 215-230.

Cushion, C. (2006). The coach as a reflective practitioner. In R. L. Jones (Ed.), The Sport Coach as Educator: Reconceptualising sport soaching (pp. 113-127). London: Routledge.

Cushion, C. \& Jones, R. L. (2006). Power, discourse, and symbolic violence in professional youth soccer: The case of Albion football club. Sociology of Sport Journal, 23, 142-161.

Cushion, C. J., Nelson, L., Armour, K. M., Lyle, J., Jones, R., Sandford, R. \& O’Callaghan, C. (2010). Coach learning and development: A review of literature. Leeds: Sportscoach UK. 
Cushion, C. \& Townsend, R. (2016). Jean Lave: Learning in coaching as social praxis. In L. Nelson., R. Groom., \& P. Potrac (Eds.), Learning in sports coaching: Theory and application (pp. 189-201). London: Routledge.

Cushion, C. (2011). Coach and athlete learning: a social approach. In Jones, R. L., Potrac, P., Cushion, C. \& Ronglan, L. T. (Eds.), The sociology of sports coaching (pp. 166-178). London: Routledge.

Day, D. \& Newton, J. (2016). John Dewey: Experience, inquiry, democracy, and community in coaching. In L. Nelson., R. Groom., \& P. Potrac (Eds.), Learning in sports coaching: Theory and application (pp. 37-48). London: Routledge.

'FA' The English Football Association (2009). http://www.thefa.com

Frith, H. \& Gleeson, K. (2004). Clothing and embodiment: Men managing body image and appearance. Psychology of Men and Masculinity, 5, 40-48.

Giddens, A. (1979). Central problems in social theory: action, structure and contradiction in social analysis. London: Macmillan.

Giddens, A. (1987). Social theory and modern sociology. Cambridge: Polity in association with Blackwell.

Giddens, A. (1991). Modernity and self-identity: Self and society in the late modern age. Cambridge: Polity.

Groom, R., Nelson, L., Potrac, P. \& Coyles, A. (2016). Burrhus Frederic Skinner: Environmental reinforcement in coaching. In L. Nelson., R. Groom., \& P. Potrac (Eds.), Learning in sports coaching: Theory and application (pp. 9-21). London: Routledge.

Hager, P. \& Hodkinson, P. (2009). Moving beyond the metaphor of transfer of learning. British Educational Research Journal, 35, 619-638.

Hansman, C. A. (2001). The new update on adult learning theory. New Directions for Adult and Continuing Education, 89, 43-52.

Holland, D., \& Lave, J. (2009). Social practice theory and the historical production of persons. An International Journal of Human Activity Theory, 2, 1-15.

Jarvis, P. (1993). Adult education and the state: Towards a politics of adult education. London: Routledge.

Jarvis, P. (2006). Towards a comprehensive theory of learning. London: Routledge.

Jones, R. (1990). Coach-player interaction: A descriptive analysis of certified football association coaches' teaching basic techniques at the youth sport level. British Journal of Physical Education Supplement, 7, 6-10.

Jones, R. (1992). Certified football association coaches: Background, training and role perceptions. British Journal of Physical Education Supplement, 12, 2-6. 
Jones, R. L., Armour, K. M. \& Potrac, P. (2004) Sports coaching cultures: from practice to theory. London: Routledge.

Jones, R. L., \& Turner, P. (2006). Teaching coaches to coach holistically: Can problem-based learning (PBL) help? Physical Education and Sport Pedagogy, 11, 181-202.

Kidman, L. \& Lombardo, B. J. (2010). Athlete-centred coaching: Developing decision makers $\left(2^{\text {nd }}\right.$ ed.). Worcester: IPC Resources.

Kilgore, D. (2001). Critical and postmodern perspectives on adult learning. In S. Merriam (Ed.). The New Update on Adult Learning Theory. San Fransisco: Jossey-Bass.

Lave, J. \& Wenger, E. (1991). Situated learning: legitimate peripheral participation. Cambridge: Cambridge University Press.

Lave, J., \& Wenger, E. (1996). Practice, person, social world. In H. Daniels (Ed.), An introduction to Vygotsky (pp. 143-150). London: Routledge.

Lave, J. \& Packer, M. (2008). Towards a social ontology of learning. In K. Nielsen, S. Brinkmann, C. Emholdt, L. Tanggaard, P. Musaeus, \& G. Kraft (Eds.), A qualitative stance: In memory of Steinar Kvale, 1938-2008, (pp. 17-47). Aarhus: Aarhus University Press.

Lave, J. (2009). The practice of learning. In K. Illeris (Ed.), Contemporary Theories of Learning (pp. 200-208). Abingdon: Routledge.

Lyle, J. (2002). Sports coaching concepts: A framework for coaches' behaviour. London: Routledge.

Mallet, C. J., Rynne, S. B. \& Billett, S. (2016). Valued learning experiences of early career and experienced high-performance coaches. Physical Education and Sport Pedagogy, 21, 89104.

Mead, G. H. (1934). Mind, Self, and Society: From the standpoint of a social behaviorist. Chicago: University of Chicago Press.

Nelson, L. Cushion, C. \& Potrac, P. (2013). Enhancing the provision of coach education: the recommendations of UK coaching practitioners. Physical Education and Sport Pedagogy, 18, 204-218.

Nelson, L., Potrac, P., Groom, R., \& Maskrey, C. (2016). Paulo Freire: Problem-posing coach education. In L. Nelson., R. Groom., \& P. Potrac (Eds.), Learning in sports coaching: Theory and application (pp. 137-149). London: Routledge.

Packer, M. J. \& Goicoechea, J. (2000). Sociocultural and constructivist theories of learning: Ontology, not just epistemology. Educational Psychologist, 35, 227-241.

Patton, M. (1990). Qualitative research method ( $2^{\text {nd }}$ edn.). Thousand Oaks, CA: Sage Publications. 
Potrac, P., Jones, R. L. \& Armour, K. (2002). “It's about getting respect'”: The coaching behaviours of a top-level English football coach. Sport, Education and Society, 7, 183-202.

Potrac, P., Nelson, L., Groom, R. \& Greenough, K. (2016). Lev Vygotsky: Learning through social interaction in coaching. In L. Nelson., R. Groom., \& P. Potrac (Eds.), Learning in sports coaching: Theory and application (pp. 101-112). London: Routledge.

Purdy, L. (2014). Interviews. In L. Nelson, R. Groom \& P. Potrac (Eds.), Research methods in sports coaching (pp. 161-170). London: Routledge.

Purdy L. G. \& Potrac, P. (2014). Am I just not good enough? The creation, development and questioning of a high performance coaching identity. Sport, Education and Society, http://dx.doi.org/10.1080/13573322.2014.941795.

Quinn, R. W., Huckleberry, S. \& Snow, S. (2012). The national youth soccer license: The historical reflections, evaluation of coaching efficacy and lessons learned. Journal of Coaching Education, National Association for Sport and Physical Education (NASPE), 5, 2039.

Rowley, C. \& Lester, C. (2016). Carl Rogers: Person-centred learning in coaching. In L. Nelson., R. Groom., \& P. Potrac (Eds.), Learning in sports coaching: Theory and application (pp. 75-85). London: Routledge.

Sparkes, A. C. \& Smith, B. (2014). Qualitative research methods in sport, exercise and health: From process to product. London: Routledge.

Stodter, A. \& Cushion, C. J. (2014). Coaches' learning and education: a case study of cultures in conflict. Sports Coaching Review, 3, 63-79.

Strauss, A. \& Corbin, J. (1990). Basics of qualitative research. Grounded theory procedure and techniques. London: Sage.

Thomas, G., Morgan, K., \& Harris, K. (2016). Albert Bandura: Observational learning in coaching. In L. Nelson., R. Groom., \& P. Potrac (Eds.), Learning in sports coaching: Theory and application (pp. 22-33). London: Routledge.

Toner, J., Moran, A., \& Gale, L. (2016). Jean Piaget: Learning and the stages of athlete development. In L. Nelson., R. Groom., \& P. Potrac (Eds.), Learning in sports coaching: Theory and application (pp. 89-100). London: Routledge.

Trudel, P., Culver, D., \& Richard, J-P. (2016). Peter Jarvis: Lifelong coach learning. In L. Nelson., R. Groom., \& P. Potrac (Eds.), Learning in sports coaching: Theory and application (pp. 202-214). London: Routledge.

Wenger, E. (1998). Communities of practice: Learning, meaning and identity. Cambridge: Cambridge University Press. 